\title{
PEMAKSIMALAN DAYA KELUARAN SEL SURYA MENGGUNAKAN LENSA CEMBUNG
}

\author{
Oleh: \\ Budhi Priyanto 1
}

\begin{abstract}
ABSTRAK: Penggunaan kumpulan lensa cembung meningkatkan intensitas berkas cahaya matahari. Lensa cembung baik yang disusun secara mendatar maupun secara melengkung dan diletakkan diatas panel sel surya pada jarak $15 \mathrm{~cm}$ dibawah lensa mampu menaikkan daya keluaran sel surya.lensa cembung yang disusun secara mendatar dapat menaikkan daya keluaran sel surya diatas $25 \%$ sedangkan lensa yang disusun secara melengkung mampu menaikkan daya keluaran diatas $50 \%$. Jadi penggunaan lensa cembung dapat memaksimalkan daya keluaran sel surya.
\end{abstract}

Katakunci: Sel surya, lensa cembung

\begin{abstract}
The use of a collection of convex lens is maximized the power output of solar cells. Convex lenses arranged either in a horizontal or in a curve. The lens was placed above the solar cell panel at a distance of $15 \mathrm{~cm}$ below the lens. The circuit was able to increase the power output of solar cells. Convex lenses arranged horizontally can increase the power output of solar cells above $25 \%$ while the lenses are arranged in a curved able to increase the output power above $50 \%$.
\end{abstract}

Keywords: Solar cells, convex lens

\section{PENDAHULUAN}

Matahari sebagai sumber energy utama alam semesta setiap saat selalu memancarkan energinya dengan cara radiasi. Bumi sebagai salah satu planet dalam system tata surya setiap saat menerima energy radiasi matahari tersebut. Dengan temperature pemukaan matahari sebesar $6000^{\circ} \mathrm{C}$ matahari memancarkan energy rata-rata $1200 \mathrm{watt} / \mathrm{m}^{2}$. Dengan energi 1200 watt $/ \mathrm{m}^{2}$ dapat digunakan untuk energi listrik rumah tangga masyarakat secara umum di Indonesia. Apabila teknologi konversi energi matahari menjadi energi listrik telah mencapai efisiensi $100 \%$ maka setiap rumah tangga hanya perlu ruang terbuka $1 \mathrm{~m}^{2}$ untuk kebutuhan listriknya. Tetapi sampai saat ini teknologi sel surya belum mampu mencapai efisiensi tersebut sehingga perlu adanya upaya-upaya untuk memaksimalkan daya keluaran dari sel surya.[4,5,6]

Sel surya bekerja berdasarkan efek fotolistrik, dimana bila sebuah cahaya diradiasikan pada permukaan bahan, maka electron akan terlepas dari permukaan bahan tersebut menjadi electron bebas. Electron bebas baru terbentuk jika cahaya yang diradiasikan memiliki energi sekurang-kurangnya sama dengan fungsi kerja dari logam tersebut. Electron yang terlepas tersebut biasa dikenal sebagai electron foto dan mempunyai energi kinetic yang bergantung pada energi berkas cahaya yang datang pada permukaan logam. Banyaknya electron yang terlepas dari permukaan logam sangat dipengaruhi oleh intensitas berkas cahaya datang. Semakin tinggi intensitas berkas cahaya datang semakin banyak pula jumlah electron foto.[1]

\footnotetext{
${ }^{1}$ Jurusan Fisika Universitas Muhammadiyah Malang (budhi@umm.ac.id)
} 
Bahan semikonduktor secara umum terbuat dari atom-atom bervalensi 4 yang memerlukan 4 elektron dari atom lain untuk memenuhi kuota electron terluarnya. Silicon sebagai komponen utama memerlukan 4 atom silicon lainnya untuk membentuk ikatan kovalen dan menjadi kristal silicon murni. Untuk melepaskan sebuah electron pada ikatan antar atom silicon menjadi electron bebas diperlukan energi dari luar sebesar $1,1 \mathrm{ev}$. Energi ini dapat berupa panas, cahaya, medan elektromagnetik atau gelombang elektromagnetik. Apabila mendapatkan energi dari luar ikatan kovalen antar atom bergetar dan electron terlepas dari ikatannya jika energi dari luar tersebut semakin besar. Jika electron terlepas dari ikatannya akan meninggalkan hole yang bermuatan positif dan menjadi electron bebas yang bermuatan negatif. Elektron dan hole ini meningkat sifat konduktivitas listrik bahan. Pada temperatur kamar kristal silicon murni adalah isolator. Selain berikatan dengan sesama atom valensi 4 atom Si dapat juga berikatan dengan atom valensi 3 dan valensi 5 untuk membentuk ketidakmurnian. Jika atom Si berikatan dengan valensi 3 membentuk semikonduktor tipe $\mathrm{P}$ yang bermuatan positif, sedang jika berikatan dengan atom valensi 5 menjadi semikonduktor tipt $\mathrm{N}$ yang bermuatan negatif. Untuk melepaskan electron dari atom Si yang berikatan dengan atom valensi 5 hanya diperlukan sedikit energi dari luar. Untuk melepaskan 1 elektron dari ikatannya hanya diperlukan energi dari luar sebesar 0,01 ev. Dalam temperatur kamar didapatkan energi sebesar 0,025 ev. Jadi pada temperatur kamar silicon dengan ketidakmurnian valensi 5 telah terdapat electron bebas dan bersifat semikonduktor.[4,5,7]

Sel surya akan menghasilkan daya keluaran yang sangat bergantung pada intensitas berkas cahaya matahari yang menyinari permukaannya. Intensitas matahari yang diterima oleh permukaan bumi tergantung pada letaknya. Tempat yang berada pada daerah tropis berbeda dengan yang berada pada daerah lainnya. Pada penelitian terdahulu dengan kudul "Peningkatan daya keluaran sel surya dengan penambahan intensitas berkas cahaya matahari" didapatkan peningkatan daya keluaran lebih dari 25\%. Penambahan intensitas dilakukan dengan cara meletakkan kumpulan lensa cembung dengan panjang focus $30 \mathrm{~cm}$ sebanyak 30 buah yang disusun mendatar. Sel surya diletakkan pada jarak $25 \mathrm{~cm}$ dibawah kumpulan lensa tersebut. Dari hasil pengamatan bahwa daya keluaran sel surya masih dapat ditingkatkan lagi dengan cara menambah intensitas berkas cahaya matahari. Hal ini disebabkan berkas cahaya yang dikumpulkan oleh lensa masih menyebar. Melihat hal tersebut penulis membuat penelitian dengan judul " Pemaksimalan daya keluaran sel surya dengan menggunakan lensa cembung". Penelitian dilakukan dengan meletakkan kumpulan lensa cembung sebanyak 30 buah dengan panjang focus $30 \mathrm{~cm}$ disusun secara melengkung. Penyusunan lensa secara lengkung dengan tujuan untuk mendapatkan berkas cahaya yang dikumpulkan oleh lensa terfokus pada satu bidang sehingga intensitas cahaya matahari meningkat lebih tinggi. [2,3]

\section{HASIL DAN PEMBAHASAN}

Untuk mendapatkan hasil yang diharapkan percobaan dilakukan dengan cara meletakkan panel sel surya pada jarak $15 \mathrm{~cm}$ dibawah kumpulan lensa cembung yang disusun secara melengkung. Daya keluaran sel surya setelah berkas cahaya dikumpulkan oleh lensa diukur dan dibandingkan dengan daya keluaran sel surya tanpa dilewatkan lensa 
untuk mengetahui besarnya perubahan daya keluaran. Panel sel surya yang digunakan mempunyai spesifikasi sebagai berikut:
a. Jenis
: monocristalin silicon solar
b. $\mathrm{P}_{\max }$
: 10 watt
c. $\mathrm{V}_{\mathrm{mp}}$
$: 18$ volt
d. $I_{m p}$
: 0,56 ampere
e. $\mathrm{V}_{\mathrm{oc}}$
: 21,6 volt
f. $I_{\mathrm{sc}}$
: 0,59 ampere
g. $\mathrm{V}_{\max }$ system : 600 volt
h. Size : $340 \times 280 \times 22 \mathrm{~mm}$
i. Test condition : $\mathrm{Am} 5 \cdot 25^{\circ} \mathrm{C} 1000 \mathrm{watt} / \mathrm{m}^{2}$

Peralatan utama yang diperlukan antara lain:
a. Avometer digital
b. Lensa cembung panjang focus $30 \mathrm{~cm}$ sebanyak 30 buah
c. Kerangka tempat kumpulan lensa berbentuk lengkung dan tempat panel sel surya
d. Stop watch

Percobaan dilakukan pada saat cuaca cerah pada musim penghujan dan dilakukan masing-masing lima hari dimulai pada pukul 10.00. pengukuran dilakukan setiap selang waktu 30 menit. Hasil pengukuran diperlihatkan pada table berikut:

Tabel 1.Hasil pengukuran hari pertama

\begin{tabular}{cccc}
\hline No. & $\begin{array}{c}\text { Waktu } \\
\text { pengukuran }\end{array}$ & $\begin{array}{c}\text { Daya keluaran tanpa } \\
\text { menggunakan lensa (watt) }\end{array}$ & $\begin{array}{c}\text { Daya keluaran } \\
\text { menggunakan lensa (watt) }\end{array}$ \\
\hline 1 & $10.00-10.30$ & 3,81 & 6,32 \\
2 & $10.30-11.00$ & 4,62 & 6,81 \\
3 & $11.00-11.30$ & 6,01 & 8,45 \\
4 & $11.30-12.00$ & 6,80 & 11,18 \\
5 & $12.00-12.30$ & 8,01 & 10,72 \\
6 & $12.30-13.00$ & 8,26 & 8,87 \\
7 & $13.00-13.30$ & 6,59 & 8,47 \\
8 & $13.30-14.00$ & 5,80 & 7,85 \\
\hline
\end{tabular}

Tabel 2.Hasil pengukuran hari kedua

\begin{tabular}{cccc}
\hline No. & $\begin{array}{c}\text { Waktu } \\
\text { pengukuran }\end{array}$ & $\begin{array}{c}\text { Daya keluaran tanpa } \\
\text { menggunakan lensa (watt) }\end{array}$ & $\begin{array}{c}\text { Daya keluaran dengan } \\
\text { menggunakan lensa (watt) }\end{array}$ \\
\hline 1 & $10.00-10.30$ & 4,40 & 9,78 \\
2 & $10.30-11.00$ & 4,61 & 10,12 \\
3 & $11.00-11.30$ & 5,01 & 11,57 \\
4 & $11.30-12.00$ & 6,79 & 12,01 \\
5 & $12.00-12.30$ & 7,41 & 10,57 \\
6 & $12.30-13.00$ & 7,82 & 9,75 \\
7 & $13.00-13.30$ & 5,41 & 9,14 \\
8 & $13.30-14.00$ & 4,82 & 7,36 \\
\hline
\end{tabular}


Tabel 3. Hasil pengukuran hari ketiga

\begin{tabular}{cccc}
\hline No. & Waktu pengukuran & $\begin{array}{c}\text { Daya keluaran tanpa } \\
\text { menggunakan lensa (watt) }\end{array}$ & $\begin{array}{c}\text { Daya keluaran dengan } \\
\text { menggunakan lensa (watt) }\end{array}$ \\
\hline 1 & $10.00-10.30$ & 3,82 & 6,13 \\
2 & $10.30-11.00$ & 4,81 & 6,85 \\
3 & $11.00-11.30$ & 5,03 & 8,33 \\
4 & $11.30-12.00$ & 6,80 & 9,40 \\
5 & $12.00-12.30$ & 7,80 & 8,08 \\
6 & $12.30-13.00$ & 8,20 & 7,28 \\
7 & $13.00-13.30$ & 5,02 & 6,81 \\
8 & $13.30-14.00$ & 4,63 & 6,39 \\
\hline
\end{tabular}

Tabel 4. Hasil pengukuran hari keempat

\begin{tabular}{cccc}
\hline No. & Waktu pengukuran & $\begin{array}{c}\text { Daya keluaran tanpa } \\
\text { menggunakan lensa (watt) }\end{array}$ & $\begin{array}{c}\text { Daya keluaran dengan } \\
\text { menggunakan lensa (watt) }\end{array}$ \\
\hline 1 & $10.00-10.30$ & 4,60 & 8,16 \\
2 & $10.30-11.00$ & 4,81 & 10,37 \\
3 & $11.00-11.30$ & 5,61 & 11,22 \\
4 & $11.30-12.00$ & 7,20 & 11,64 \\
5 & $12.00-12.30$ & 7,81 & 11,43 \\
6 & $12.30-13.00$ & 8,23 & 8,17 \\
7 & $13.00-13.30$ & 7,82 & 7,70 \\
8 & $13.30-14.00$ & 5,62 & 6,14 \\
\hline
\end{tabular}

Tabel 5. Hasil pengukuran hari kelima

\begin{tabular}{cccc}
\hline No. & Waktu pengukuran & $\begin{array}{c}\text { Daya keluaran tanpa } \\
\text { menggunakan lensa (watt) }\end{array}$ & $\begin{array}{c}\text { Daya keluaran dengan } \\
\text { menggunakan lensa (watt) }\end{array}$ \\
\hline 1 & $10.00-10.30$ & 4,41 & 9,30 \\
2 & $10.30-11.00$ & 5,01 & 11,03 \\
3 & $11.00-11.30$ & 5,82 & 14,21 \\
4 & $11.30-12.00$ & 7,41 & 10,74 \\
5 & $12.00-12.30$ & 7,82 & 9,20 \\
6 & $12.30-13.00$ & 6,23 & 8,78 \\
7 & $13.00-13.30$ & 5,03 & 8,13 \\
8 & $13.30-14.00$ & 4,82 & 7,66 \\
\hline
\end{tabular}

Dari hasil pengukuran hari pertama sampai hari kelima rata-rata daya keluaran dan kenaikan daya keluaran saat tanpa menggunakan lensa dan saat menggunakan lensa disusun secara melengkung diperlihatkan pada table 6 . 
Table 6. Rata-rata daya keluaran dan kenaikan daya keluaran

\begin{tabular}{ccccc}
\hline No. & Waktu pengukuran & $\begin{array}{c}\text { Daya keluaran } \\
\text { tanpa lensa (watt) }\end{array}$ & $\begin{array}{c}\text { Daya keluaran } \\
\text { dengan lensa (watt) }\end{array}$ & $\begin{array}{c}\text { Kenaikan daya } \\
\text { keluaran }(\%)\end{array}$ \\
\hline 1 & $10.00-10.30$ & 4,28 & 7,936 & 84,453 \\
2 & $10.30-11.00$ & 4,77 & 9,036 & 89,392 \\
3 & $11 / 00-11.30$ & 5,596 & 10,756 & 92,308 \\
4 & $11.30-12.00$ & 7.00 & 10,994 & 57,05 \\
5 & $12.00-12.30$ & 7,77 & 10,00 & 28,7 \\
6 & $12.30-13.00$ & 7,748 & 8,45 & 9,0 \\
7 & $13.00-13.30$ & 5,974 & 8,05 & 34,75 \\
8 & $13.30-14.00$ & 5,138 & 7,08 & 35,85 \\
\hline
\end{tabular}

Rata-rata kenaikan daya keluaran $=\frac{\text { jumla h kenaikan daya }}{\text { banyaknya pengukuran }}=\frac{431,503}{8}=53,94 \%$

Grafik hubungan antara waktu penyinaran dan daya keluaran sel surya tanpa menggunakan lensa dan menggunakan lensa diperlihatkan pada gambar1.

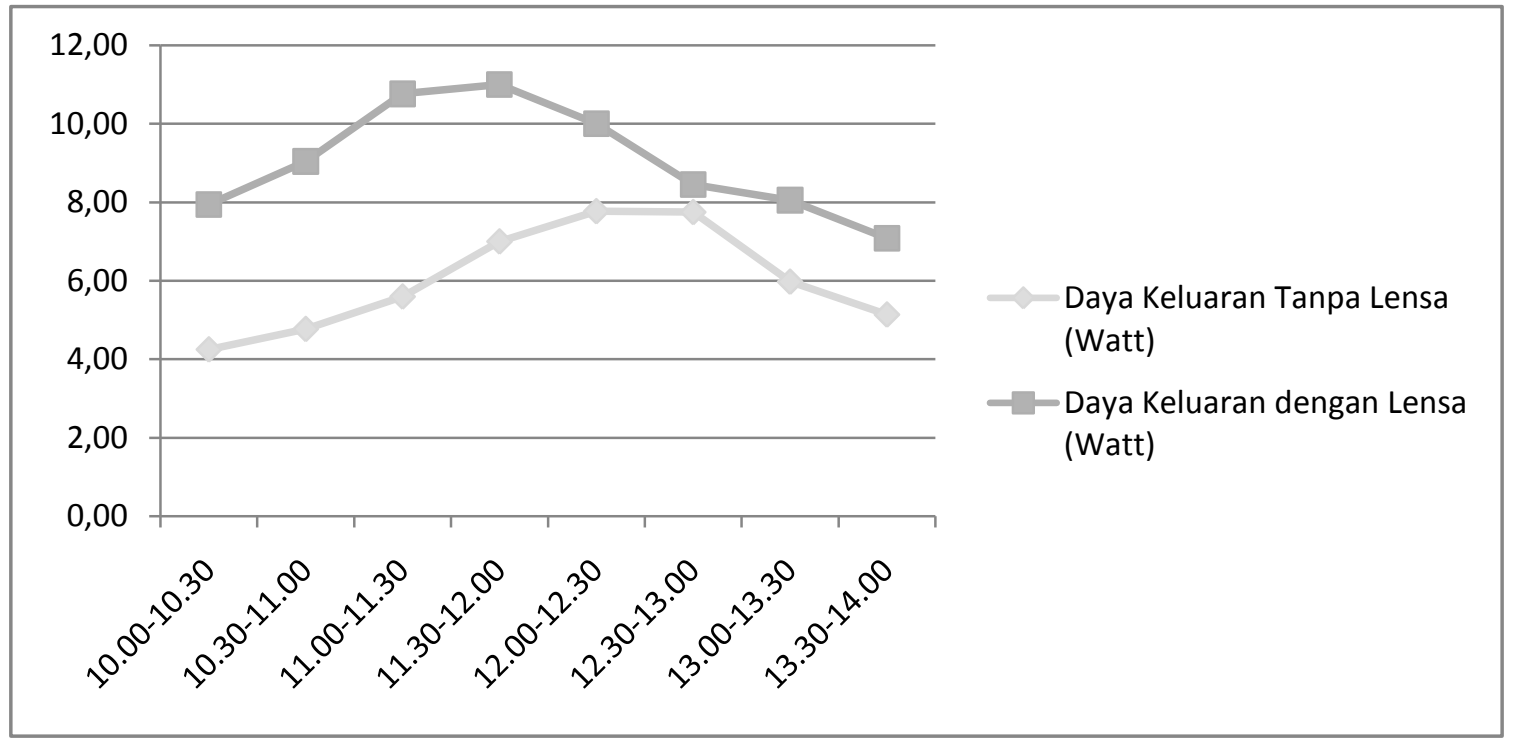

Gambar 1. Grafik hubungan antara waktu penyinaran dan daya keluaran sel surya

Dari grafik gambar 1 telihat bahwa daya keluaran sel surya semakin meningkat dengan bertambahnya waktu penyinaran. Daya keluaran mencapai maksimum pada waktu tertentu yaitu saat intensitas cahaya maksimum kemudian turun dengan turunnya intensitas cahaya. Hal ini terlihat saat penyinaran antara pukul 11.30-12.00 sel surya dengan menggunakan lensa mempunyai daya keluaran maksimum, sedangkan sel surya tanpa menggunakan lensa daya maksimum terjadi antara pukul 12.00-12.30. Pola gambar antara sel surya menggunakan lensa dan tidak menggunakan lensa mempunyai bentuk grafik identik sehingga penggunaan lensa tidak mengubah karakteristik sel surya. Terdapat perbedaan daya keluaran yang dihasilkan oleh sel surya pada saat digunakan lensa dan tidak. Saat digunakan lensa daya keluaran sel surya lebih besar dari daya keluaran saat tidak menggunakan lensa. Pada saat menggunakan lensa yang disusun secara melengkung 
didapatkan daya keluaran maksimum sebesar 10,994 watt. Daya ini melebihi daya maksimum panel sel surya sebesar 10 watt. Sedangkan saat tidak digunakan lensa daya maksimum yang terjadi 7,748 watt yang masih dibawah daya keluaran maksimum panel sel surya. Jadi kumpulan lensa cembung yang disusun secara melengkung dapat memaksimalkan daya keluaran sel surya.

\section{KESIMPULAN}

Dari hasil pengukuran dan analisa dapat disimpulkan bahwa:

1. Penggunaan kumpulan lensa cembung yang disusun secara melengkung dapat meningkatkan daya keluaran sel surya'

2. Penggunaan kumpulan lensa cembung mampu memaksimalkan daya keluaran sel surya dan dapat melebihi daya keluaran maksimum panel sel surya.

3. Daya keluaran meningkat dengan meningkatnya intensitas berkas cahaya matahari dan turun ketika intensitas mengalami penurunan.

4. Peningkatan daya keluaran pada percobaan dengan meletakkan kumpulan 30 lensa cembung disusun secara melengkung diatas panel sel surya pada jarak $15 \mathrm{~cm}$ mencapai 53,94\%

\section{DAFTAR PUSTAKA}

[1] Arthur Beiser (The Houw Liong, PhD). 1982. Konsep Fisika Modern. Erlangga

[2] Budhi priyanto \& Vikko Rosiadi. 2012. Peningkatan Daya Keleluaran Sel Surya Dengan Menambah Intensitas Cahaya Melalui Lensa Cembung. Laporan penelitian UMM

[3] Brelin Aprilista, Budhi priyant, 2013. Alat Bantu Pengisi Cepat Sel Surya Menggunakan Lensa Cembung Berbentuk Parabola. Laporan penelitian UMM

[4] Martin A. Green. 1982. Solar Cells. prentice Hall

[5] S.M.Sze , John wiley \& Sons, 1985 ,Semiconductor Devices(Physics And Technology).

[6] Sears\& Zemansky, 1992, Fisika Universitas. Binacipta

[7] Ir. S. Rekario \& Dr. Masamori Iida. 1982. Fisika dan Teknologi Semokonduktor. Pradya Paramita. Jakarta 